Nig. J. Biotech. Vol. 36 (2) : $33-44$ (Dec 2019)

ISSN: 01891731

Available online at

NIGERIAN JOURNAL OF

BIOTECHNOLOGY

http://www.ajol.info/index.php/njb/index

and www.biotechsocietynigeria.org

DOI: https://dx.doi.org/10.4314/njb.v36i2.5

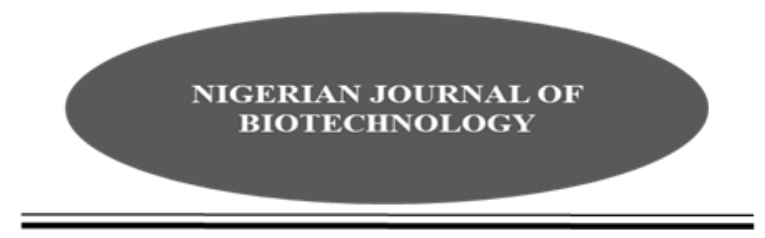

\title{
Assessment of genetic diversity of selected cowpea landraces from Nigeria based on simple sequence repeat markers
}

\author{
Iseghohi I.0.1, 2, 3 , Adesoye A.I. ${ }^{2}$, Oludare D.A. ${ }^{2}$, Agunbiade F.V. ${ }^{2}$ and \\ Unachukwu N. ${ }^{3}$ \\ ${ }^{1}$ Department of Crop Science and Horticulture, Federal University, Oye-Ekiti, Ekiti State, Nigeria \\ ${ }^{2}$ Department of Botany, University of Ibadan, Ibadan, Nigeria \\ ${ }^{3}$ Bioscience Laboratory, International Institute of Tropical Agriculture (IITA), Ibadan, Oyo State, Nigeria
}

\begin{abstract}
Understanding the genetic diversity of cowpea (Vigna unguiculata L. Walp.) landraces is useful for effective characterization and ex-situ conservation of germplasm. The analysis of genetic diversity of eighteen cowpea landraces collected from five agro-ecological zones in Nigeria was reported in this study. Five individuals per landrace were genotyped with six polymorphic microsatellite markers. Three to 5 alleles with a mean of 3.833 were detected. Mean Polymorphic information content (PIC) and observed heterozygosity of the markers were 0.5721 and 0.2433, respectively. Analysis of Molecular Variance (AMOVA) showed that variation due to agroecological zone constituted $24 \%$, while variations among and within landraces as well as within individuals constituted $25 \%, 17 \%$ and $33 \%$, respectively. Landraces collected from the humid rainforest zone showed high within landrace diversity and were not significantly different $(P \geq 0.001)$ from other landraces collected from the same zone. Landraces from the savannah zones showed low within landrace diversity and homozygous across all loci. Consequently, among landrace diversity was higher in the savannah zone with landraces collected from guinea savannah been the most diverse, followed by landraces from the derived savannah and Sudan savannah. Mantel test showed positive and significant correlation $(r=0.377, p=0.01)$ between genetic and geographical distance of landrace collections. The findings are important for up-to-date characterizations of cowpea germplasm in Nigeria for improved breeding programs.
\end{abstract}

Keywords: Genetic diversity, cowpea, Alleles, Polymorphic information content, AMOVA,

*Corresponding author: innocent.iseghohi@fuoye.edu.ng, +234-8038147675

\section{Introduction}

Cowpea (Vigna unguicuilata L.Walp.) $(2 \mathrm{n}=2 \mathrm{x}=$ 22) belongs to the family Fabaceae. It is an annual grain legume predominantly grown in the northern parts of Nigeria and widely consumed across the country especially for its high protein (23-29 \%) content (Boukar et al., 2016). The seed is rich in lysine, tryptophan, folic acids and vitamins (Nielson et al., 1993). The young leaves and immature pods are consumed in some parts of the country while stems, leaves and vines serve as animal feeds. Africa accounts for about $95 \%$ of the total world production and Nigeria is the largest producer of cowpea in the world accounting for $61 \%$ production in 
Africa and $58 \%$ worldwide (IITA, 2015). Nigerian cowpea landraces show high variability in seed shapes, sizes, colours, texture, pigmentation and growth habits. Farmers predominantly grow the brown-seeded and white-seeded types which are most preferred by consumers (Mishili et al., 2009).

Generally, landraces are the most diverse populations in cultivated plants (Frankel et al., 1995). They are diverse mixtures of different genotypes and thus show variability within and between accessions. They represent valuable resources that can be explored for the introgression of new genes in varietal improvement (Hedge and Mishra, 2009; Xu et al., 2010). Landraces are generally defined as a population of cultivated plants with a historical background, identity and are adapted to local environment but without any breeding improvement (Camacho-Villa et al., 2005). They are also called 'farmer-developed accessions' or 'traditional varieties'. Resource-poor farmers grow these unimproved landraces despite the availability of improved cultivars (Bellon and Hellin, 2011; Kamara et al., 2012). In pulses like pigeonpea and chickpea, traditional landraces or selections from them are released directly as varieties (Hegde and Mishra, 2009).

Since early 1970 s, numerous cowpea landraces have been sampled from different parts of Nigeria and preserved at the seed bank of the Genetic Resources Centre of the International Institute of Tropical Agriculture (IITA) and the National Centre for Genetic Resources and Biotechnology (NACGRAB), Ibadan, Nigeria. Socio-economic changes and drought however, led to a dramatic reduction of cowpea landraces cultivation recently (African Centre for Biodiversity, 2015) and probably to the disappearance of local populations. Data on diversity assessment of these farmer-developed accessions are scarce. To stem this loss of genetic variation, conservation and reconnaissance of existing biodiversity are fundamental. Characterization of most cowpea accessions in these gene banks are based mainly on morphological data which are fraught with environmental variations (Nkongolo, 2003; Ibrahima et al., 2013). Molecular markers, particularly Simple Sequence Repeats (SSR), are playing an increasingly important role in assessment, characterization and conservation of plant genetic resources. The sequences are abundant and randomly distributed throughout the genome, highly polymorphic, inherited codominantly, and are not influenced by environmental variations and have shown great potential for various genetic studies (Tautz, 1989; Ibrahima et al., 2014; Jingade et al., 2014). They have been used to assess the diversity of various cowpea germplasm from different countries (Li et al., 2001; Ogunkanmi et al., 2008; Asare et al., 2010; Gupta and Gopalakrishma, 2010; Ogunkanmi et al., 2014; Adesoye et al., 2016; Wamalwa et. al., 2016).

Genetic diversity between cowpea landraces has been reported, however, few studies have analyzed the diversity within landraces that are held ex situ (Singh et al., 1991; Gomez et al., 2004). Most studies would bulk DNA from several individuals per landrace (Toklu et al., 2009; Adetiloye et al., 2013) thus masking the inherent variation within each landrace. Molecular assessment of diversity within and between cowpea landraces will help to ascertain variations that exist within them and classify them into distinct groups for enhanced breeding programme. Therefore, the objectives of this study were to assess the genetic diversity within and among cowpea accessions earlier collected in various parts of Nigeria and conserved in IITA and NACGRAB gene banks.

\section{Materials and Methods}

\section{Planting Materials and description of collection}

Eighteen cowpea accessions collected from eighteen states across five agroecological zones in Nigeria and curated in the genetic resource centers of IITA and NACGRAB, Ibadan, Nigeria were used for the experiment (Table 1). At least two states from each agroecological zone were represented in the sample. The place and coordinates of collection as well as the growth habits of the accessions were obtained from the genetic resource centers.

\section{DNA Extraction}

Two seeds per landrace were sown in five pots filled with sterilized soil. The pots were arranged in complete randomized design in a screen house. Two weeks after planting, fresh leaves 
were collected from five plants per landrace for DNA extraction. The leaves were collected in properly labeled nylons on dried ice pack and total genomic DNA was extracted using the modified Dellaporta et al. (1983) protocol. Extracted DNA was washed in $300 \mu$ of $70 \%$ ethanol centrifuged at $3500 \mathrm{rpm}$ for 10 minutes twice. DNA pellets were dried at room temperature for 1 hour, dissolved in $110 \mu \mathrm{lTE}$ and $1 \mu$ of RnaseA. It was gently mixed and incubated at $37^{\circ} \mathrm{C}$ for 30 minutes. Quantification was done using spectrophotometer ND-1000 (Thermo Scientific, Wilmington, DE, USA). DNA was stored at $-20^{\circ} \mathrm{C}$ for subsequent uses. The research was carried out at the Bioscience laboratory of the International Institute for Tropical Agriculture (IITA), Ibadan, Nigeria.

Table 1: Passport data of cowpea accessions collected from eighteen states in Nigeria used in the study

\begin{tabular}{|c|c|c|c|c|c|c|c|c|c|}
\hline $\begin{array}{l}\mathbf{S} / \\
\mathbf{N}\end{array}$ & Accession no. & $\begin{array}{l}\text { Collection } \\
\text { location }\end{array}$ & $\begin{array}{l}\text { Agro- } \\
\text { zones }\end{array}$ & Lat. & Long. & $\begin{array}{l}\text { Altitude } \\
\text { (m) }\end{array}$ & $\begin{array}{l}\text { Seed } \\
\text { colour }\end{array}$ & $\begin{array}{l}\text { Growth } \\
\text { habit }\end{array}$ & Source \\
\hline 1 & Tvu-3926 & Abuja & $\begin{array}{l}\text { Derived } \\
\text { Sav. }\end{array}$ & $9.06^{\circ} \mathrm{N}$ & $7.48^{\circ} \mathrm{E}$ & 456 & $\begin{array}{l}\text { White/B } \\
\text { rown }\end{array}$ & $\begin{array}{l}\text { Semi- } \\
\text { prostrate }\end{array}$ & IITA \\
\hline 2 & Tvu-10982 & Kwara & $\begin{array}{l}\text { Derived } \\
\text { Sav. }\end{array}$ & $8.83^{\circ} \mathrm{N}$ & $5.0^{\circ} \mathrm{E}$ & 394 & White & Semi-erect & IITA \\
\hline 3 & NG/AO/11/08/089 & Lokoja, & $\begin{array}{l}\text { Derived } \\
\text { Sav. }\end{array}$ & $7.0^{\circ} \mathrm{N}$ & $6.7^{\circ} \mathrm{N}$ & 89 & Cream & Semi-erect & NACGRAB \\
\hline 4 & Tvu-7842 & Oyo & $\begin{array}{l}\text { Derived } \\
\text { Sav. }\end{array}$ & $8.0^{\circ} \mathrm{N}$ & $4.0^{\circ} \mathrm{E}$ & 315 & Cream & $\begin{array}{l}\text { Semi- } \\
\text { prostrate }\end{array}$ & IITA \\
\hline 5 & Tvu-4320 & Gombe & $\begin{array}{l}\text { Guinea } \\
\text { Sav. }\end{array}$ & $10^{\circ} \mathrm{N}$ & $11^{\circ} \mathrm{E}$ & 461 & White & $\begin{array}{l}\text { Semi- } \\
\text { prostrate }\end{array}$ & IITA \\
\hline 6 & NG/MR/11/11/066 & Jos & $\begin{array}{l}\text { Guinea } \\
\text { Sav. }\end{array}$ & $9.4^{\circ} \mathrm{N}$ & $9.2^{\circ} \mathrm{E}$ & 1,238 & White & Prostrate & NACGRAB \\
\hline 7 & NG/SA/07/0306 & Niger & $\begin{array}{l}\text { Guinea } \\
\text { Sav. }\end{array}$ & $10.0^{\circ} \mathrm{N}$ & $6.0^{\circ} \mathrm{E}$ & 329 & Brown & Creeping & NACGRAB \\
\hline 8 & NG/SA/07/166 & Yola, & $\begin{array}{l}\text { Guinea } \\
\text { Sav. }\end{array}$ & $9.23^{\circ} \mathrm{N}$ & $12.5^{\circ} \mathrm{E}$ & 181 & Brown & Semi-erect & NACGRAB \\
\hline 9 & Tvu-9304 & Delta & $\begin{array}{l}\text { Humid } \\
\text { Forest }\end{array}$ & $5.5^{\circ} \mathrm{N}$ & $6.0^{\circ} \mathrm{E}$ & 44 & Brown & Semi-erect & IITA \\
\hline 10 & $\begin{array}{l}\text { NG/OA/MAR/09/01 } \\
0\end{array}$ & Edo & $\begin{array}{l}\text { Humid } \\
\text { Forest }\end{array}$ & $6.5^{\circ} \mathrm{N}$ & $6.0^{\circ} \mathrm{E}$ & 88 & White & Prostrate & NACGRAB \\
\hline 11 & Tvu-4053 & Imo & $\begin{array}{l}\text { Humid } \\
\text { Forest }\end{array}$ & $5.52^{\circ} \mathrm{N}$ & $6.92^{\circ} \mathrm{E}$ & 138 & Cream & Prostrate & IITA \\
\hline 12 & NG/AT/APR/09/017 & Ogun & $\begin{array}{l}\text { Humid } \\
\text { Forest }\end{array}$ & $7.00^{\circ} \mathrm{N}$ & $3^{\circ} 35^{\prime} \mathrm{E}$ & 116 & White & Prostrate & NACGRAB \\
\hline 13 & Tvu-10862 & Ondo & $\begin{array}{l}\text { Humid } \\
\text { Forest }\end{array}$ & $7.08^{\circ} \mathrm{N}$ & $4.83^{\circ} \mathrm{E}$ & 194 & Brown & Creeping & IITA \\
\hline 14 & Tvu-3890 & Borno & Sahel Sav. & $11.9^{\circ} \mathrm{N}$ & $13.3^{\circ} \mathrm{E}$ & 325 & $\begin{array}{l}\text { Brown/B } \\
\text { lack }\end{array}$ & intermediate & IITA \\
\hline 15 & Tvu-818 & Yobe & Sahel Sav. & $11.7^{\circ} \mathrm{N}$ & $12.2^{\circ} \mathrm{E}$ & 351 & Black & intermediate & IITA \\
\hline 16 & NG/SA/07/0133 & Kaduna & Sudan Sav. & $10.30^{\circ} \mathrm{N}$ & $8.12^{\circ} \mathrm{E}$ & 634 & White & Erect & NACGRAB \\
\hline 17 & Tvu-663 & Kano & Sudan Sav. & $12.0^{\circ} \mathrm{N}$ & $8.5^{\circ} \mathrm{E}$ & 469 & Cream & $\begin{array}{l}\text { Semi- } \\
\text { prostrate }\end{array}$ & IITA \\
\hline 18 & $\mathrm{NG} / \mathrm{AO} / 11 / 08 / 44$ & Katsina & Sudan Sav. & $12.25^{\circ} \mathrm{N}$ & $7.5^{\circ} \mathrm{E}$ & 508 & Brown & Creeping & NACGRAB \\
\hline
\end{tabular}




\section{PCR Amplification of Microsatellite loci}

DNA samples across the landraces were randomly selected, pooled and tested with fifteen SSR markers. Six polymorphic markers were then selected for the study (Table 2). Amplification of selected SSR primers was performed in $25 \mu$ l reaction volume using Gene AMPR PCR system 9700 Thermocycler (Applied Biosystems). The reaction mixtures consisted of $2.0 \mu \mathrm{l}$ of DNA, $0.3 \mu \mathrm{l}$ Taq polymerase, $1.5 \mu \mathrm{l}$ of SSR primers, $0.8 \mu$ of dNTPs (deoxynucleotide triphosphates), $1.0 \mu \mathrm{l}$ of $10 \times$ buffer, $1.0 \mu \mathrm{l}$ of $\mathrm{MgCl}_{2}$ and $3.14 \mu \mathrm{l}$ of ultra-pure water under the following temperature profile: 1 cycle of $95^{\circ} \mathrm{C}$ for 2 min, followed by 39 cycles of denaturation at $94^{\circ} \mathrm{C}$ for $30 \mathrm{~s}$, annealing at $50-65^{\circ} \mathrm{C}$ for $30 \mathrm{~s}$, and extension at $72^{\circ} \mathrm{C}$ for $30 \mathrm{~s}$, and a final extension at $72^{\circ} \mathrm{C}$ for $5 \mathrm{~min}$. PCR products were resolved on $6 \%$ silver stained denaturing polyacrylamide gel electrophoresis (PAGE) along with a $1 \mathrm{~kb}$ standard DNA ladder (Invitro gene). Bands were scored manually as present or absent under white light illuminator. The presence of allele was scored 1 while the absence of allele was scored 0 . Unamplified bands were declared missing data.

Statistical Analyses of Molecular Data
Allele number observed and expected
heterozygosity or gene diversity and
polymorphic information content (PIC) were
calculated across all loci using Powermaker
V3.25 (Liu and Muse 2005). Gene diversity and
heterozygosity within each landrace were also
calculated in Powermarker. Analysis of molecular
variance (AMOVA) was calculated in GenAlex 6.5
(Peakall and Smouse 2012) based on the linear
statistical model described by Weir and
Cockerham (1984): $\mathrm{P}_{\mathrm{ijkz}}=\mathrm{P}+\mathrm{A}_{\mathrm{z}}+\mathrm{B}_{\mathrm{kz}}+\mathrm{C}_{\mathrm{jkz}}+\mathrm{D}_{\mathrm{ijkz} ;}$

Table 2: SSR Markers, their nucleotide sequence and base pair length

\begin{tabular}{|c|c|c|c|}
\hline Markers & Nucleotide sequence $5^{\prime}-3^{\prime}$ & $\begin{array}{l}\text { Fragment } \\
\text { size (bp) }\end{array}$ & Reference \\
\hline VM9 & $\begin{array}{l}\text { F: ACCGCACCCGATTTA } \\
\text { R: ATCAGCAGACAGGCA }\end{array}$ & 271 & Ogunkanmi et al.2008 \\
\hline VM 31 & $\begin{array}{l}\text { F: CGCTCTTCGTTGATGGTTATG } \\
\text { R: GTCTTCTAGAGGGTGTGATGGTA }\end{array}$ & 200 & Cyrus et al.2017 \\
\hline VM 37 & $\begin{array}{l}\text { F: TGTCCGCGTTCTATAAAT } \\
\text { R: CGAGGATGAAGTAACAGA }\end{array}$ & 289 & $\begin{array}{l}\text { Ogunkanmi et al.2008, Ali } \\
\text { et al.2015 }\end{array}$ \\
\hline VM 40 & $\begin{array}{l}\text { F: TATTACGAGAGGCTATTT } \\
\text { R: CTCTAACACCTCAAGTTA }\end{array}$ & 200 & Ali et al.2015 \\
\hline VM51 & $\begin{array}{l}\text { F: CATTGCCACCTGGTTTCACTTA } \\
\text { R: GAGGCTCAGCATTTTGTTTCTAT }\end{array}$ & 256 & Ali et al.2015 \\
\hline VM 53 & $\begin{array}{l}\text { F: GAGTTCCGTTCGTTGTGAGTAGAG } \\
\text { R:ACAGAGGAGGAAAAGGAAGTATGC }\end{array}$ & 288 & Ali et al.2015 \\
\hline
\end{tabular}

Where, $P_{i j k z}$ indexes the $i^{\text {th }}$ allele in the $j^{\text {th }}$ individuals within $k^{\text {th }}$ landraces in $z^{\text {th }}$ agroecological zone. A represents the effects of the agroecological zone, $B$ is the effects of landrace and $C$ is the effects of individuals within landraces while $D$ is the effects of alleles within each individual.

Wright's $F$ statistics for the AMOVA was based on 999 pair wise population permutation (Wright 1951; Weir and Cockerham, 1984). Nei's genetic distance matrices among landraces (Nei 1979) were used to construct dendrograms based on
Unweighted Pair Group Method with Arithmetic means (UPGMA). Dendrograms were drawn and visualized in Mega 6 (Tamura et al., 2013).

\section{Results}

Marker information

The Markers detected 3 to 5 alleles with mean allele number of 3.8333 (Table 3). VM 9 and VM 53 detected 3 alleles, respectively while VM 37, VM 40 and VM 51 detected 4 alleles, respectively. VM 31 detected the highest number of alleles of 5 . Major allele frequency 
ranged between 0.3466 and 0.5747 with an average of 0.4683 . Gene diversity or expected heterozygosity $(\mathrm{He})$ ranged between 0.5231 and 0.7195 with a mean of 0.6376 . VM 37 had the highest gene diversity (0.7195) while VM 53 had the lowest gene diversity (0.5231). Observed heterozygosity ranged between 0.1839 and 0.2614 with a mean of 0.2433 . VM 51 and VM
53 recorded the highest observed heterozygosity of 0.2614 , respectively while VM 9 had the least observed heterozygosity (0.1839). Polymorphic information content ranged between 0.4174 and 0.6681 with a mean of 0.5721 . VM 31 had the highest PIC value of 0.6681 while VM 53 had the least PIC value of 0.4174 .

Table 3: Marker information of six SSR loci across ninety cowpea plants of eighteen landraces from Nigeria

\begin{tabular}{llllll}
\hline Marker & Major allele Frequency & Allele Number & $\begin{array}{l}\text { Gene } \\
\text { diversity (He) }\end{array}$ & $\begin{array}{l}\text { Heterozygosity } \\
\text { (Ho) }\end{array}$ & PIC \\
\hline VM 9 & 0.4470 & 3.0000 & 0.6357 & 0.1839 & 0.5641 \\
VM 31 & 0.3663 & 5.0000 & 0.7195 & 0.2558 & 0.6681 \\
VM 37 & 0.4942 & 4.0000 & 0.6416 & 0.2442 & 0.5811 \\
VM 40 & 0.5747 & 4.0000 & 0.6074 & 0.2529 & 0.5639 \\
VM 51 & 0.3466 & 4.0000 & 0.6985 & 0.2614 & 0.6380 \\
VM 53 & 0.5511 & 3.0000 & 0.5231 & 0.2614 & 0.4174 \\
Mean & 0.4683 & 3.8333 & 0.6376 & 0.2433 & 0.5721 \\
\hline
\end{tabular}

He: Expected heterozygosity, Ho: Observed heterozygosity, PIC: Polymorphic Information Content

\section{Population structure}

Analysis of molecular variance (AMOVA) partitioned the overall variation of the cowpea landraces into four components: Variation due to agroecological zones, variation among and within landraces and variation within individuals (Table 4). Variation due to agroecological zone of landrace collections constituted $24 \%$, variation among the landraces accounted for 25 $\%$, while variations among and within individuals accounted for $17 \%$ and $33 \%$, respectively. The genetic variations in the four levels were significant $(p<0.001)$.

\section{Genetic diversity measure within landraces}

To assess genetic diversity within each landrace; allele number, gene diversity and heterozygosity of five individual plants within each landrace were estimated (Table 5). There was no genetic diversity within landrace NG/MR/11/11/066 collected from Jos, as gene diversity (GD) and heterozygosity ( $\mathrm{Ho})$ values were 0.00 , respectively. One and same allele was detected across the five individuals of this landrace. Conversely, Tvu-10862 from Ondo had the highest gene diversity and heterozygosity values of 0.573 and 1.000 , respectively, followed by NG/OA/MAR/09/010, from Edo (GD=0.530, $\mathrm{Ho}=$ 0.967), Tvu-4053, Imo $(\mathrm{GD}=0.529, \mathrm{Ho}=$ 1.000), Tvu-9304, Delta (GD $=0.537, \mathrm{Ho}=0.856)$ and NG/AT/APR/09/017, Ogun $(G D=0.525$, Ho $=0.800)$. Other landraces mainly from the savannah zones had gene diversity values ranging from 0.063 to 0.463 . However, their heterozygosity was zero and thus homozygous.

Genetic diversity among landraces based on cluster analysis and pairwise genetic distance

Dendrogram (Figure 1) based on UPGMA formed three major distinct clusters of the eighteen landraces. Cluster I comprises of Tvu-3890 (Borno) and Tvu-818 (Yobe) landraces, both of the Sahel savannah. 
Iseghohi et al / Nig. J. Biotech. Vol. 36 Num. 2 : 33 - 44 (December 2019)

Table 4: Analysis of Molecular variance of eighteen cowpea landraces from Nigeria

\begin{tabular}{lccccccc}
\hline Source & df & SS & MS & Est. Var. & \% & F-Statistics & P-value \\
\hline $\begin{array}{l}\text { Among Agro- } \\
\text { Zone }\end{array}$ & 4 & 100.642 & 25.161 & 0.520 & 24 & 0.244 & 0.001 \\
$\begin{array}{l}\text { Among } \\
\text { Landraces }\end{array}$ & 13 & 88.580 & 6.814 & 0.538 & 25 & 0.334 & 0.001 \\
$\begin{array}{l}\text { Within landraces } \\
\text { Within } \\
\text { individuals }\end{array}$ & 72 & 103.500 & 1.438 & 0.366 & 17 & 0.497 & 0.001 \\
\hline
\end{tabular}

Table 5: Genetic diversity of five individuals within eighteen cowpea landraces from Nigeria

\begin{tabular}{lllll}
\hline S/N & Accession Number & Allele number & Gene diversity & Heterozygosity \\
\hline $\mathbf{1}$ & Tvu-3926 & 1.333 & 0.093 & 0.000 \\
$\mathbf{2}$ & Tvu-10982 & 1.167 & 0.063 & 0.000 \\
$\mathbf{3}$ & NG/AO/11/08/089 & 1.833 & 0.227 & 0.000 \\
$\mathbf{4}$ & Tvu-7842 & 1.167 & 0.053 & 0.000 \\
$\mathbf{5}$ & Tvu-4320 & 1.333 & 0.133 & 0.000 \\
$\mathbf{6}$ & NG/MR/11/11/066 & 1.000 & 0.000 & 0.000 \\
$\mathbf{7}$ & NG/SA/07/0306 & 1.500 & 0.160 & 0.000 \\
$\mathbf{8}$ & NG/SA/07/166 & 1.500 & 0.213 & 0.000 \\
$\mathbf{9}$ & Tvu-9304 & 2.500 & 0.537 & 0.856 \\
$\mathbf{1 0}$ & NG/OA/MAR/09/010 & 2.333 & 0.530 & 0.967 \\
$\mathbf{1 1}$ & Tvu-4053 & 2.333 & 0.529 & 1.000 \\
$\mathbf{1 2}$ & NG/AT/APR/09/017 & 2.500 & 0.525 & 0.800 \\
$\mathbf{1 3}$ & Tvu-10862 & 2.667 & 0.573 & 1.000 \\
$\mathbf{1 4}$ & Tvu-3890 & 1.167 & 0.063 & 0.000 \\
$\mathbf{1 5}$ & Tvu-818 & 1.500 & 0.187 & 0.000 \\
$\mathbf{1 6}$ & NG/SA/07/0133 & 2.167 & 0.463 & 0.000 \\
$\mathbf{1 7}$ & Tvu-663 & 2.167 & 0.440 & 0.000 \\
$\mathbf{1 8}$ & NG/AO/11/08/44 & 2.000 & 0.333 & 0.000 \\
\hline
\end{tabular}

Cluster II consists of two sub clusters in which the first sub cluster comprises of Tvu-10982 (Kwara), Tvu-3926(Abuja) and Tvu-7842 (Oyo); all belonging to the derived savannah zone while the second sub cluster comprises of NG-MR-1111-066 (Jos landrace), NG-AO-11-08-089 (Lokoja) and Tvu-4320 (Gombe). The landraces of Jos and Gombe belong to the guinea savannah zone while the Lokoja landrace belongs to the derived savannah zone. Cluster III formed four sub clusters with the first sub cluster having NG-AO-11-08-44 (Katsina landrace) and NG-SA-07-0133 (Kaduna landrace) i.e landraces of the Sudan savannah zone, while the second sub cluster comprises of NG-SA-07-0306 (Niger landrace) and NG-SA-07166 (Yola landrace) i.e landraces of the guinea savannah zone. Landrace Tvu-663 collected from Kano stood alone in the third cluster while landraces (NG-OA-MAR-09-010, Tvu-9304, Tvu4053, NG-AT-APR-09-017 and Tvu-10862) collected from Edo, Delta, Imo, Ogun and Ondo, respectively all in the humid forest zone formed two sub clusters.

Pairwise Fst values between landraces and their corresponding test of significance are presented in table 6. Fst values ranged from 0.00 (Tvu- 
3926 and Tvu-7842) to 0.90 (Tvu-3926 and $\mathrm{NG} / \mathrm{MR} / 11 / 11 / 066)$, indicating that Tvu-3926 and Tvu-7842 are the most similar landraces while Tvu-3926 and NG/MR/11/11/066 are the most different landraces. Fst values between (NG/AT/APR/09/017 and Tvu-9304), (NG/OA/MAR/09/010 and Tvu-9304), (NG/OA/MAR/09/010 and Tvu-4053), (NG/OA/MAR/09/010 and NG/AT/APR/09/017), (NG/OA/MAR/09/010 and Tvu-10862), (Tvu-
4053 and NG/AT/APR/09/017), (TVu-4053 and Tvu-10862), (NG/AT/APR/09/017 and Tvu10862), (NG/SA/07/0133 and NG/AO/11/08/44) showed that each pair of landrace is not significantly different $(P \geq 0.001)$.

Matrix of pairwise genetic distance and geographic distance of landrace collections showed positive and significant correlation ( $r=$ $0.377, p=0.01$ ) based on Mantel test.

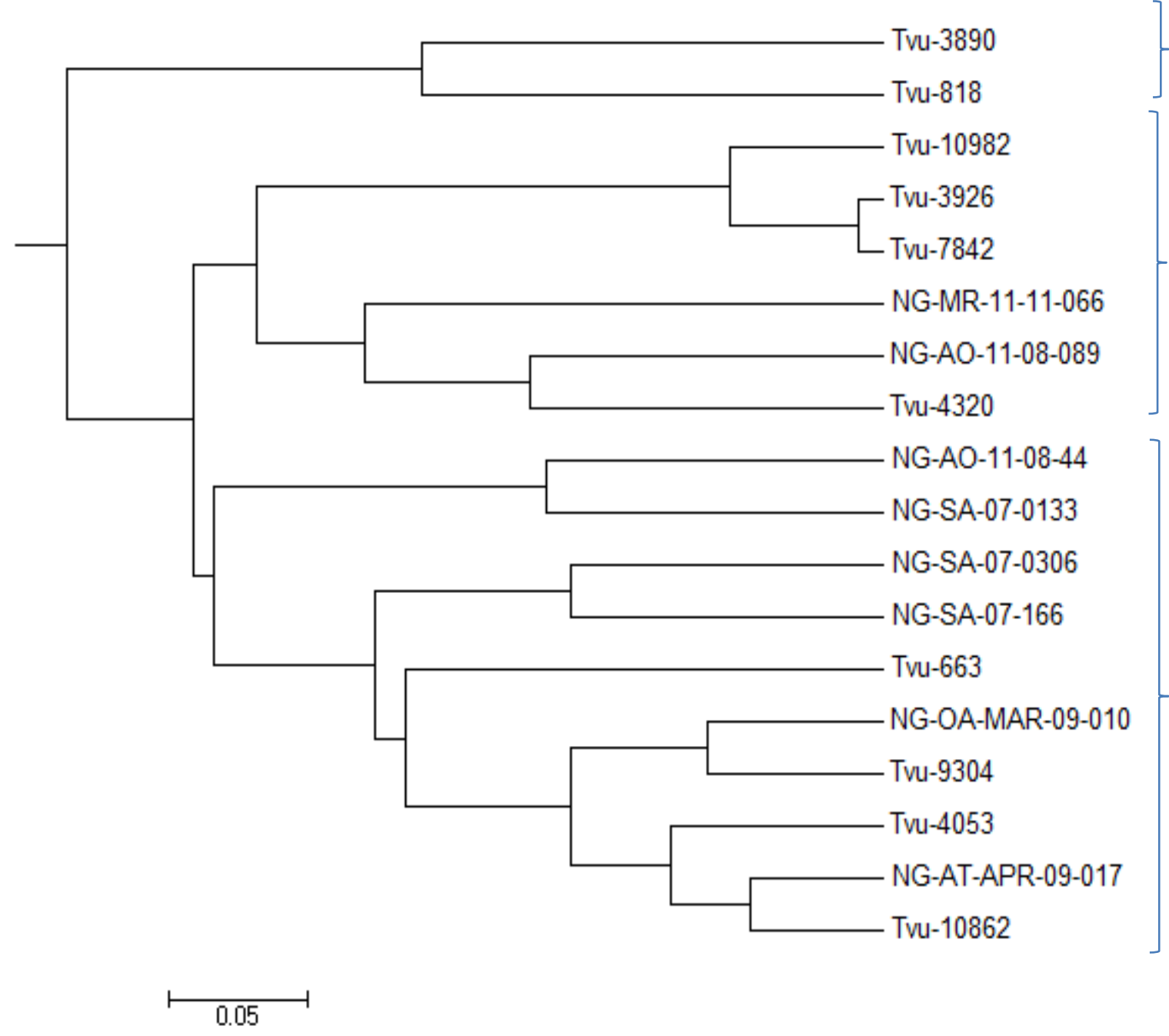

Cluster II

Cluster III

Figure 1: Genetic diversity of eighteen cowpea landraces from Nigeria 
Iseghohi et al / Nig. J. Biotech. Vol. 36 Num. 2 : 33 - 44 (December 2019)

Table 6: Fst pairwise matrix of eighteen cowpea landraces selected from Nigeria

\begin{tabular}{|c|c|c|c|c|c|c|c|c|c|c|c|c|c|c|c|c|c|c|}
\hline SN & 1 & 2 & 3 & 4 & 5 & 6 & 7 & 8 & 9 & 10 & 11 & 12 & 13 & 14 & 15 & 16 & 17 & 18 \\
\hline 1 & 0.00 & & & & & & & & & & & & & & & & & \\
\hline 2 & $0.31 *$ & $0.00 *$ & & & & & & & & & & & & & & & & \\
\hline 3 & $0.60 *$ & $0.46 * *$ & $0.00^{* * *}$ & & & & & & & & & & & & & & & \\
\hline 4 & -0.00 & $0.32 * *$ & $0.63^{* * *}$ & 0.00 & & & & & & & & & & & & & & \\
\hline 5 & $0.72 *$ & $0.64 * *$ & $0.50^{* * *}$ & $0.75^{* * *}$ & $0.00 * * *$ & & & & & & & & & & & & & \\
\hline 6 & $0.90 *$ & $0.81^{* *}$ & $0.67 * * *$ & $0.93 * * *$ & $0.82 * * *$ & $0.00^{* * *}$ & & & & & & & & & & & & \\
\hline 7 & $0.75 *$ & $0.72 * *$ & $0.72^{* * *}$ & $0.79 * * *$ & $0.71^{* * *}$ & $0.86^{* * *}$ & $\begin{array}{l}0.00 * * \\
*\end{array}$ & & & & & & & & & & & \\
\hline 8 & $\begin{array}{l}0.69 * \\
* *\end{array}$ & $\begin{array}{l}0.66 * * \\
*\end{array}$ & $0.59 * * *$ & $0.73^{* * *}$ & $0.49 * * *$ & $0.73^{* * *}$ & $\begin{array}{l}0.42^{* *} \\
*\end{array}$ & 0.00 & & & & & & & & & & \\
\hline 9 & $\begin{array}{l}0.49 * \\
* *\end{array}$ & $\begin{array}{l}0.43 * * \\
*\end{array}$ & $0.33^{* * *}$ & $0.53^{* * *}$ & $0.36^{* * *}$ & $0.43^{* * *}$ & $\begin{array}{l}0.41^{* *} \\
*\end{array}$ & $\begin{array}{l}0.34 * * \\
*\end{array}$ & 0.00 & & & & & & & & & \\
\hline 10 & $\begin{array}{l}0.53 * \\
* *\end{array}$ & $\begin{array}{l}0.46 * * \\
*\end{array}$ & $0.41^{* * *}$ & $0.57^{* * *}$ & $0.40^{* * *}$ & $0.57^{* * *}$ & $\begin{array}{l}0.36^{* *} \\
*\end{array}$ & $0.27^{* *}$ & $0.072^{\mathrm{ns}}$ & 0.00 & & & & & & & & \\
\hline 11 & $\begin{array}{l}0.46 * \\
* *\end{array}$ & $\begin{array}{l}0.38 * * \\
*\end{array}$ & $0.36^{* * *}$ & $0.51^{* * *}$ & $0.52^{* * *}$ & $0.60^{* * *}$ & $\begin{array}{l}0.42^{* *} \\
*\end{array}$ & $\begin{array}{l}0.40 * * \\
*\end{array}$ & $0.14 *$ & $0.11^{\mathrm{ns}}$ & 0.00 & & & & & & & \\
\hline 12 & $\begin{array}{l}0.44 * \\
* *\end{array}$ & $\begin{array}{l}0.40 * * \\
*\end{array}$ & $0.36^{* * *}$ & $0.48^{* * *}$ & $0.43 * * *$ & $0.53 * * *$ & $\begin{array}{l}0.38^{* *} \\
*\end{array}$ & $0.31^{* *}$ & $0.06^{\mathrm{ns}}$ & $0.07^{\mathrm{ns}}$ & $0.10^{\mathrm{ns}}$ & 0.00 & & & & & & \\
\hline 13 & $\begin{array}{l}0.38 * \\
* *\end{array}$ & $\begin{array}{l}0.30 * * \\
*\end{array}$ & $0.31^{* * *}$ & $0.42^{* * *}$ & $0.46^{* * *}$ & $0.53 * * *$ & $\begin{array}{l}0.39 * * \\
*\end{array}$ & $0.32 * *$ & $0.135^{* *}$ & $0.10^{\mathrm{ns}}$ & $0.03^{\mathrm{ns}}$ & $0.04^{\mathrm{ns}}$ & 0.00 & & & & & \\
\hline 14 & $\begin{array}{l}0.88 * \\
* *\end{array}$ & $\begin{array}{l}0.79 * * \\
*\end{array}$ & $0.80 * * *$ & $0.91^{* * *}$ & $0.83^{* * *}$ & $0.93^{* * *}$ & $\begin{array}{l}0.80 * * \\
*\end{array}$ & $\begin{array}{l}0.78^{* *} \\
*\end{array}$ & $0.47^{* * *}$ & $\begin{array}{l}0.48^{* *} \\
*\end{array}$ & $\begin{array}{l}0.52^{* *} \\
*\end{array}$ & $\begin{array}{l}0.52^{* *} \\
*\end{array}$ & $\begin{array}{l}0.54 * * \\
*\end{array}$ & 0.00 & & & & \\
\hline 15 & $\begin{array}{l}0.77 * \\
* *\end{array}$ & $\begin{array}{l}0.71 * * \\
*\end{array}$ & $0.67^{* * *}$ & $0.81^{* * *}$ & $0.55^{* * *}$ & $0.82^{* * *}$ & $\begin{array}{l}0.64 * * \\
*\end{array}$ & $\begin{array}{l}0.52 * * \\
*\end{array}$ & $0.25^{* * *}$ & $0.25 * *$ & $\begin{array}{l}0.41^{* *} \\
*\end{array}$ & $\begin{array}{l}0.33 * * \\
*\end{array}$ & $\begin{array}{l}0.41 * * \\
*\end{array}$ & $\begin{array}{l}0.61^{* *} \\
*\end{array}$ & 0.00 & & & \\
\hline 16 & $\begin{array}{l}0.46 * \\
*\end{array}$ & $0.30 * *$ & $0.25^{* *}$ & $0.48^{* * *}$ & $0.41^{* * *}$ & $0.56^{* * *}$ & $\begin{array}{l}0.52 * * \\
*\end{array}$ & $\begin{array}{l}0.47 * * \\
*\end{array}$ & $0.20 * *$ & $\begin{array}{l}0.23^{* *} \\
*\end{array}$ & $0.19 *$ & $0.22^{* *}$ & $0.15 *$ & $\begin{array}{l}0.50 * * \\
*\end{array}$ & $0.47 * * *$ & 0.00 & & \\
\hline 17 & $\begin{array}{l}0.52 * \\
* *\end{array}$ & $\begin{array}{l}0.50 * * \\
*\end{array}$ & $0.54 * * *$ & $0.57 * * *$ & $0.58^{* * *}$ & $0.61^{* * *}$ & $\begin{array}{l}0.32 * * \\
*\end{array}$ & $\begin{array}{l}0.42^{* *} \\
*\end{array}$ & $0.21 *$ & $0.20 *$ & $0.15^{*}$ & $0.16^{*}$ & $0.13 *$ & $\begin{array}{l}0.52 * * \\
*\end{array}$ & $0.44 * * *$ & $0.17^{*}$ & 0.00 & \\
\hline 18 & $\begin{array}{l}0.68 * \\
* *\end{array}$ & $\begin{array}{l}0.55 * * \\
*\end{array}$ & $0.38^{* * *}$ & $0.70^{* * *}$ & $0.55^{* * *}$ & $0.52^{* * *}$ & $\begin{array}{l}0.64 * * \\
*\end{array}$ & $\begin{array}{l}0.52 * * \\
*\end{array}$ & $0.22 * * *$ & $\begin{array}{l}0.31 * * \\
*\end{array}$ & $0.30 * *$ & $\begin{array}{l}0.31 * * \\
*\end{array}$ & $0.24 * *$ & $\begin{array}{l}0.62^{* *} \\
*\end{array}$ & $0.54 * * *$ & $0.10^{\mathrm{ns}}$ & $\begin{array}{l}0.30 * \\
*\end{array}$ & 0.00 \\
\hline
\end{tabular}

Ns= Nonsignificant; $*=P \geq 0.05 ; * *=P \geq 0.01 ; * * *=P \geq 0.001 ; 1,2 \ldots 18=$ Serial number of landraces as defined in table1

\section{Discussion}

Simple sequence repeat markers were idea to discriminate alleles within and between landraces selected from some states across five agroecological zones of Nigeria. Markers detected 1 to 5 alleles depending on the type of SSR marker. VM 31 detected 5 alleles and a PIC value of 0.6681 while VM 9 and VM 53 detected 3 alleles each with corresponding PIC values of 0.5641 and 0.4174 , respectively. In earlier reports, Adetiloye et al. (2013) reported 2 to 4 alleles in some Nigerian cowpea landraces based on SSR markers while Ogunkanmi et al. (2014) reported allele number of 2 to 5 using 14 SSR markers to assay cultivated cowpea collected across Africa. The average PIC value of 0.5721 obtained in this study indicates that the markers were polymorphic. Bostein et al. (1980) stated that PIC value $>0.5$ is highly polymorphic and suitable to discriminate alleles of germplasm. Polymorphic information content values of 0.37 and 0.38 lower than the one obtained in this study have previously been reported in cowpea SSR markers (Ogunkanmi et al., 2008; Asare et 
al., 2010; Adetiloye et al., 2013). However, Ibrahima et al. (2014) reported a higher PIC of 0.83 in his assessment of cowpea germplasms from Ghana and Mali. Mangini et al. (2010) stated that the discriminating ability of each marker is dependent on its PIC and resolving power (Rp) and not necessarily the number of markers used. Chen et al. (2017) and Mafakheri et al. (2017), though used 54 and 22 SSR in assessment of cowpea accessions, however recorded an average allele number of 2.9 and 2, respectively. They also obtained relative low PIC values of 0.3615 and 0.445 , respectively.

Genetic diversity among five individuals within each cowpea landraces constituted $17 \%$ of the total variation while variation within the 90 individuals across the loci constituted $33 \%$ of the total variation in this study. There was no genetic diversity within NG/MR/11/11/066 landrace collected from Jos; consequently, gene diversity and heterozygosity values were zero. Most of the landraces assessed, especially those from the savannah zones had low gene diversity and consequently were homozygous across all loci. However, landraces from the humid forest zone had high gene diversity and heterozygous across the loci. Different levels of genetic diversity within cowpea landraces have previously been reported. Gomez et al. (2004) reported that two-thirds of the variation observed in Nicaraguan common bean landraces was distributed within the landraces; while Chen et al. (2017) reported a $52 \%$ within population variation in 105 cowpea accessions collected from China, Kenya, Nigeria and Niger. However, Ali et al. (2015) reported a relative low diversity of $9 \%$ within 231 cowpea landraces obtained from Sudan. In this study, genetic diversity within the landraces collected from the savannah agroecological zones is relatively low. This is however common in cowpea as the crop is predominantly self-pollinating in nature with moderate to high outcrossing levels (Gepts 1993; Graham and Ranalli, 1997). We refrained to adjudge any reason to the high genetic diversity observed within the landraces collected from the humid forest zone. Similar result was reported by Gomez et al. (2004) in which one out of four zones assessed in their study recorded high genetic diversity within common bean landraces. They attributed the high genetic diversity of the landraces within the zone to outcrossing at the farm level with resultant gene flow between diverse individuals of same or different landrace(s). Therefore, landraces with broad genetic bases remain reservoir of novel genes for introgression in improving desirable traits in cowpea breeding programs.

Based on the dendrogram, most landraces belonging to same agroecological zones formed same cluster except NG-MR-11-11-066 (Jos landrace) and Tvu-4320 (Gombe) of guinea savannah which clustered with landraces of the derived savannah because of their low within landrace diversity. Similarly, Tvu-663 (Kano landrace) clustered with landraces of humid forest zone because of its high within landrace diversity. Pairwise Fst values among landraces of the humid zone showed that the genetic distances among most of the landraces of this zone were not significant. The genetic distance among the landraces NG/AT/APR/09/017 (Ogun), Tvu-9304 (Delta), NG/OA/MAR/09/010 (Edo), Tvu-4053 (Imo), and Tvu-10862 (Ondo) was not significant. Similarly, the difference between NG/SA/07/0133 (Kaduna) and NG/AO/11/08/44 (Katsina) both of Sudan savannah zone was not significant while Tvu3926 (Abuja) and Tvu-7842 (Oyo), belonging to derived savannah zone were genetically identical. This could be attributed to 'founder effect' in which landraces within the same zone have common ancestor. It could also be due to farmers' preference to adapt specific landrace(s) to an agroecology and exchange seeds because of their good performance. Nevertheless, some landraces though collected from the same agroecological zones were significantly different as found in the landraces of the guinea savannah and Sudan savannahs, respectively.

Genetic diversity among landraces and agroecological zones contributed $25 \%$ and 24 $\%$, respectively to the total genetic variation. Chen et al. (2017) reported a similar result of $23.3 \%$ genetic diversity among cowpea accessions while Mafakheri et al. (2017) reported $23 \%$ genetic diversity among 33 cowpea genotypes assessed in their study. Genetic diversity among landraces has been attributed to spatial differentiation among sites of collections (Gomez et al., 2004; Boezkowska and Tarezyk, 2013). In this study, genetic distance was positive and significantly correlated 
with geographic distance of seed collection ( $r=$ $0.377, p=0.01$ ), indicating that the variation among landraces could have been due to geographical distance among landraces. However, landraces with short distances between collection sites are not significantly different as seen in humid forest zone and the Sahel savannah zones.

\section{Conclusions}

Simple sequence repeat marker was effective in dissecting genetic diversity within and among cowpea landraces collected from five agroecological zones in Nigeria. The use of SSR marker is important as it provides useful information complementary to phenotypic and morphological characterization of these landraces held ex situ in the gene banks. In this study, there was high genetic diversity within the cowpea landraces collected from the humid forest zone. This in turn resulted in low diversity between the landraces in this zone. Conversely, there was low genetic diversity within the landraces collected from the savannah agroecological zones with consequent high genetic diversity among the landraces; especially within guinea savannah zone. The understanding of the genetic bases of the landraces assessed in this study and the distinct grouping of the landraces will help to plan future breeding programs to maximize heterosis in desired traits in cowpea breeding.

\section{Competing Interest}

The authors declare that they have no competing interest

\section{Acknowledgement}

The first author acknowledges Tertiary Education Trust Fund (TETFUND) for funding the M.Sc. programme at the University of Ibadan which forms part of this research paper.

\section{References}

Adesoye, A.I, Folayan, D.V. and Ladejobi, O.O. (2016). Genetic relationships among bacterial blight resistant cowpea (Vigna unguiculata) lines as revealed by simple sequence repeat markers. Niger. J. Genet. 31: 90-101.

Adetiloye, I.S., Ariyo, O.J., Alake, C.O., Oduwaye, O.O. and Osewa, S.O. (2013). Genetic diversity of some selected Nigeria cowpea using simple sequence repeats (SSR) marker. Afr. J. of Agric. Res. 8: 586-590.

African Centre for Biodiversity (2015). GM and seed industry eye Africa's lucrative cowpea seed markets: The political economy of cowpea in Nigeria, Burkina Faso, Ghana and Malawi. Johannesburg, SA, ACB, p. 37.

Ali, Z.B., Yao, K.N., Odeny, D.A., Kyalo, M., Skilton, R. and Eltahir, I.M. (2015). Assessing the genetic diversity of cowpea (Vigna unguiculata (L.) Walp.) accessions from Sudan using simple sequence repeat (SSR) markers. Afr. J. Plant Sci. 9: 293-304.

Asare, A.T., Gowda, B.S., Galyuon, I.K.A. and Aboagye, L.L. (2010). Assessment of the genetic diversity in cowpea (Vigna unguiculata (L.) Walp.) germplasm from Ghana using simple sequence repeat markers. Plant Genet. ResourC. 8: 142-150.

Bellon, M.R. and Hellin, J. (2011). Plant hybrids, keeping landraces: Agricultural modernization and tradition among small-scale farmers in Chapas, México. World Dev. 39: 1434-1443.

Badiane, F.A., Gowda, B.S., Cisse, N., Diouf, D., Sadio, O. and Timko, M.P. (2012). Genetic relationship of cowpea (Vigna unguiculata) varieties from Senegal based on SSR markers. Genet. Mol. Res. 11: 292-304.

Boezkowska, M. and Tarezyk, E. (2013). Genetic diversity among Polish landraces of common oat (Avena sativa L.). Genet. Resour. Crop Ev. 60: 2157-2169

Boukar, O., Fatokun, C.A., Huynh, B.L., Roberts, P.A. and Close, T.J. (2016). Genomic Tools in Cowpea Breeding Programs: Status and Perspectives. Front. Plant Sci. 7:757.

Camacho-Villa, T.C., Maxted, N., Scholten, M. and Ford-Lloyd, B. (2005). Defining and identifying crop landraces. Plant Genetic ResourC. $3: 373-384$. 
Chen, H., Chen, H., Hu, L., Wang, L., Wang, S., Wang, M., et al. (2017). Genetic diversity and a population structure analysis of accessions in the Chinese cowpea [Vigna unguiculata (L.) Walp.] germplasm collection. The Crop J. 5: 363-372.

Cyrus A., Mohammed, F., Ishiayaku, Mansir, Y. and Abdullahi, U.S. (2017). Cluster analysis and association between simple sequence repeat markers with qualitative trait in some Nigerian Achishuru cowpea landraces. Rep. Opinion 9: 20-26

Dellaporta, S.L., Wood, J., Hicks, J.B. (1983). A plant mini preparation: version II. Plant Mol. Biol. Rep. 1:19-21.

Frankel, O.H., Brown, A.H.D. and Burdon, J.J. (1995). The conservation of plant biodiversity. Cambridge, United Kingdom, Cambridge University Press, p. 280.

Gepts, P. (1993). The use of molecular and biochemical markers in crop evolution studies. Evolutionary Biology 27:51-94

Gomez, O.J., Blair, M.W., Frankow-Lindberg, B.E. and Gullerg, U. (2004). Molecular and phenotypic diversity of common bean landraces from Nicaragua. Crop Sci. 44: 1412-1418.

Graham, P.H. and Ranalli, P. (1997). Common bean (Phaseolus vugaris L.). Field Crops Res. 53: $131-146$

Gupta, S.K. and Gopalakrishna, T. (2010). Development of unigene-derived SSR markers in cowpea (Vigna unguiculata) and their transferability to other Vigna species. Genome 53: 508-523.

Hedge, V.S. and Mishra, S.K. (2009). Landraces of cowpea, (Vigna unguiculata (L.) Walp) as potential sources of genes for unique characters in breeding. Genet. Resour. Crop Ev. 56: 615627.

Ibrahima, Z.D., Richard, A. and Asibou, J.Y. (2013). Comparative study of cowpea germplasms diversity from Ghana and Mali using morphological characteristics. J. Plant Breed. Genet. 1: 139-147
Ibrahima, Z.D., Richard, A. and Asibou, J.Y. (2014). Assessment of Cowpea Germplasms from Ghana and Mali Using Simple Sequence Repeat (SSR) Markers. Intl. J. Agric. For. 4: 118123.

IITA (2015). Cowpea. Available: http://www.iita.org/cowpea. Accessed in March 2017.

Jingade, P., Bosaro, L.V., Sanjayrao, A.J., Rajanna, R., Jain, M. and Ravikumar, R.L. (2014). Characterization of microsatellite markers, their transferability to orphan legumes and use in determination of genetic diversity among chickpea (Cicer arietinum L.) cultivars. J. Crop Sci. Biotech. 17: 191-199.

Kamara, A.Y., Omoigui, L.O. and Ewansiha, S.U. (2012). Improving the productivity of cowpea in the savannas of northeast Nigeria through participatory evaluation and dissemination of improved varieties. Fifth World Cowpea Conference, Saly, Senegal, 27 September-1 October, 2010, Pp. 432.

Li, C.D., Fatokun, C.A., Ubi, B., Singh, B.B. and Scoles, G.J. (2001). Determining genetic similarities and relationships among cowpea breeding lines and cultivars by microsatellite markers. Crop Sci. 41: 189-197

Mafakheri, K., Bihamta, M. R. and Abbasi, A.R. (2017). Assessment of genetic diversity in cowpea (Vigna unguiculat L.) germplasm using morphological and molecular characterization. Cogent Food Agric. 3:3-20

Mantel, N. (1967). The detection of disease clustering and a generalized regression approach. Cancer Res. 27: 209-220

Mishili, F.J., Fulton, J., Shehu, M., Kushwaha, S., Marfo, K., Jamal, M., Kergna, A. and LowenbergDeBoer, J. (2009). Consumer preferences for quality characteristics along the cowpea value chain in Nigeria, Ghana and Mali. Agribusiness 25: $16-35$.

Nei, M. and Li, W.H. (1979). Mathematical model for studying genetic variation in terms of restriction endonucleases. Proceedings of the National Academy of Sciences (USA) 76: 52695273. 
Nielson, S.S., Brandt, W.E. and Singh, B.B. (1993). Genetic variability for nutritional composition and cooking time of improved cowpea lines. Crop Sci. 33: 469-472.

Nkongolo, K.K. (2003). Genetic characterization of Malawian cowpea (Vigna unguiculata (L.) Walp.) Landraces: diversity and gene flow among accessions. Euphytica 129: 219-228.

Ogunkanmi, L.A., Taiwo, I.A., Mogaji, O.L., Awobodede, A., Eziashi, I. and Ogundipe, O.T. (2006). Assessment of genetic diversity among cultivated cowpea (Vigna unguiculata L Walp.) cultivars from a range of localities across West Africa using agronomic traits. Journal of Science Research and Development 10: 111-118.

Ogunkanmi, L.A., Ogundipe, O.T., Ng, N.Q. and Fatokun, C.A. (2008). Genetic diversity in wild relatives of cowpea (Vigna unguiculata) as revealed by simple sequence repeats (SSR) markers. J. Food Agric. Environ. 6: 253-268.

Ogunkanmi, L.A., Ogundipe, O.T. and Fatokun, C.A. (2014). Molecular Characterization of cultivated cowpea (Vigna unguiculata L.Walp) using simple sequence repeats markers. Afr. J. Biotechnol. 13: 3464-3472.

Peakall, R. and Smouse, P.E. (2012). GenAlex 6.5: genetic analysis in Excel. Population genetic software for teaching and research-an update. Bioinformatics 28: 2537-2539.

Singh, S.P., Gutierrez, J.A., Molina, A., Urrea, C. and Gepts, P. (1991). Genetic diversity in cultivated common beans: II. Marker-based analysis of morphological and agronomic traits. Crop Sci. 31: 23-29.

Tamura, K., Stecher, G., Peterson, D., Filipski, A. and Kumar, S. (2013). MEGA6: Molecular evolutionary genetics analysis version 6.0. Mol. Biol. Evol. 30:2725-2729.

Toklu, F., Karako, T., Hakl, E., Bicer, T., Brandolini, A., Kilian, B. and Ozkan, H. (2009). Genetic variation among lentil (Lens culinaris Medik) landraces from Southeast Turkey. Plant Breed. 128: 178-186.

Wamalwa, E.N., Muoma, J. and Wekesa, C. (2016). Genetic diversity of cowpea (Vigna unguiculata (L.) Walp.) accession in Kenya gene bank based on simple sequence repeat markers. Intl. J. Genomics. http://dx.doi.org/10.1155/2016/8956412.

Weir, B.S. and Cockerham, C.C. (1984). Estimating F-Statistis for analysis of population structure. Evolution 38: 1358-1370.

Wright, S. (1951). The genetical structure of populations. Ann. Eugen. 15:323-354.

Xu, P., Wu, X.H., Wang, B.G., Liu, Y.H., Qin, D.H. and Ehlers, J.D. (2010). Development and polymorphism of Vigna unguiculata ssp. unguiculata microsatellite markers used for phylogenetic analysis in asparagus bean (Vigna unguiculata ssp. sesquipedialis (L.) Verdc.), Mol. Breed. 25 (4): 675-684.

\section{Abbreviations}

AMOVA: Analysis of molecular variance

dNTPs: Deoxynucleotide triphosphates

GD: Genetic diversity

GRC: Genetic Resource Centre

IITA: International Institute for Tropical Agriculture

NACGRAB: National Centre for Genetic Resources and Biotechnology

PAGE: Polyacrylamide gel electrophoresis

PCR: Polymerase chain reaction

PIC: Polymorphic information content

Rp: Resolving power

SSR: Simple sequence repeat marker

TE: Tris EDTA

TETFUND: Tertiary Education Trust Fund

UPGMA: Unweighted Pair Group Method with Arithmetic Means 